\title{
Transcriptional silencing in yeast is associated with reduced nucleosome acetylation
}

\author{
Miriam Braunstein,, ${ }^{1}$ Alan B. Rose, ${ }^{3}$ Scott G. Holmes, ${ }^{1}$ C. David Allis, ${ }^{2}$ and James R. Broach ${ }^{1,4}$ \\ ${ }^{1}$ Department of Molecular Biology, Princeton University, Princeton, New Jersey $08544 \mathrm{USA}^{2}$ Department of Biology, \\ Syracuse University, Syracuse, New York 13244-1220 USA
}

Two classes of sequences in the yeast Saccharomyces cerevisiae are subject to transcriptional silencing: the silent mating-type cassettes and telomeres. In this report we demonstrate that the silencing of these regions is strictly associated with acetylation of the $\epsilon$-amino groups of lysines in the amino-terminal domains of three of the four core histones. Both the silent mating-type cassettes and the $Y$ domains of telomeres are packaged in nucleosomes in vivo that are hypoacetylated relative to those packaging active genes. This difference in acetylation is eliminated by genetic inactivation of silencing: The silent cassettes from sir2, sir3, or sir4 cells show the same level of acetylation as other active genes. The correspondence of silencing and hypoacetylation of the mating-type cassettes is observed even for an allele lacking a promoter, indicating that silencing per se, rather than the absence of transcription, is correlated with hypoacetylation. Finally, overexpression of Sir2p, a protein required for transcriptional silencing in yeast, yields substantial histone deacetylation in vivo. These studies fortify the hypothesis that silencing in yeast results from heterochromatin formation and argue that the silencing proteins participate in this formation.

[Key Words: Saccharomyces cerevisiae; transcriptional silencing; mating-type cassettes; telomeres; heterochromatin formation; histone acetylation]

Received December 15, 1992; revised version accepted February 12, 1993.

Eukaryotic cells present a number of cases in which the transcription state of a gene is affected by its position within the genome. Repositioning a normally active gene near a heterochromatic region results in position effect variegation in Drosophila, in which the repositioned gene is inactivated in a subset of somatic cells as a result of variable extension of the adjacent heterochromatic domain. In the process of $\mathrm{X}$ chromosome inactivation, most of the genes on one of two essentially identical chromosomes are rendered transcriptionally inactive as a result of heterochromatization emanating from a cis-acting X-chromosome inactivation center (Lyon 1961, 1988; Brown et al. 1991). In chromosome imprinting, two homologs of a particular gene are differentially expressed solely on the basis of the parental origin of the chromosome on which the gene resides (Solter 1988; Hall 1990). In all of these cases, identical genes are regulated differently solely on the basis of their chromosomal location.

Transcriptional silencing in the yeast Saccharomyces cerevisiae provides an experimentally tractable process that exhibits many of the features of these cases of po-

Present address: ${ }^{3}$ Boyce Thompson Institute, Cornell University, Ithaca, New York 14853-1801 USA.

${ }^{4}$ Corresponding author. sition effect regulation. Transcriptional silencing is the region-specific, but sequence-nonspecific, repression exhibited by two types of loci in yeast: the homothallic mating loci (HML and $H M R$ ) and telomeres. $H M L$ and $H M R$ encompass functional but transcriptionally repressed sets of mating-type genes (Klar et al. 1981; Nasmyth et al. 1981). These same mating-type genes, when resident at the expressor locus $M A T$, are transcribed to establish and maintain the mating-type of the cell (for review, see Herskowitz 1988, 1989). At $H M L$ and $H M R$, the mating-type genes are repressed by a mechanism that is region-specific: Simply transposing the mating-type genes away from either loci yields their activation, whereas inserting other RNA polymerase II- or RNA polymerase III-transcribed genes at either locus results in repression of the inserted gene (Hicks et al. 1979; Brand et al. 1985; Schnell and Rine 1986). In a similar fashion, insertion of an otherwise active gene within the telomeric domain of several different chromosomes in yeast results in repression of the inserted gene (Gottschling et al. 1990). Finally, like chromosome imprinting, the repression state of the silenced domains exhibit epigenetic inheritance (Pillus and Rine 1989; Mahoney et al. 1991).

The genetic requirements for silencing at $H M L$ and $H M R$ and at telomeres suggest that the two types of loci 
share a common repression mechanism. First, silencing at the homothallic loci and at telomeres requires many of the same trans-acting components. Mutational inactivation of SIR2 (MAR1), SIR3 (MAR2), or SIR4 restores normal expression of genes inserted at telomeres and yields expression of the mating-type genes at $H M L$ and $H M R$ at a level equivalent to that of the genes present at $M A T$ (Haber and George 1979; Klar et al. 1979; Rine et al. 1979; Rine and Herskowitz 1987; Aparicio et al. 1991). Similarly, certain mutations of $H H F 2$, the structural gene for histone $\mathrm{H} 4$, yield complete derepression of the silent loci and activation of genes inserted at telomeres (Kayne et al. 1988; Park and Szostak 1990; Aparicio et al. 1991\}. Full repression at $H M L$ and $H M R$ requires a fifth gene, SIR1, which is not required for silencing at telomeres (Rine and Herskowitz 1987; Aparicio et al. 1991). Inactivation of SIR1, however, results in only a partial, metastable derepression of the silent cassettes (Ivy et al. 1986; Pillus and Rine 1989). This same pattern of expression is normally observed for genes inserted at telomeres (Gottschling et al. 1990). No function of any $S I R$ gene product has been defined.

Repression at $H M L$ and $H M R$ also requires specific cis-active sites, or silencers, that likely serve as foci through which the trans-acting components act (Abraham et al. 1984; Feldman et al. 1984). Silencers are composed of well-defined functional elements. Two of these elements are recognition sites for abundant, DNA-binding proteins, Raplp and Abflp; a third element is the replication origin core consensus sequence, or ARS (Brand et al. 1985; 1987; Mahoney and Broach 1989; McNally and Rine 1991). Because two of these elements are present within telomeres, they may mediate silencing within telomeres as well (Conrad et al. 1990).

Several facets of transcriptional silencing suggest that it results from altered chromatin structure. First, a variety of mutations that alter the amino-terminal domain of histone $\mathrm{H} 4$ abolish silencing of $H M L$ and $H M R$ (Kayne et al. 1988; Johnson et al. 1990; Megee et al. 1990; Park and Szostak 1990). This argues for the participation of histones in transcriptional silencing. Second, limited DNase digestions of intact yeast chromatin indicate that genes at the silent cassettes are less accessible to nucleases than are the same genes residing at MAT (Nasmyth 1982). Third, histone H3 packaging the silent cassettes is less accessible to thiol reagents than are those packaging other regions of the genome (Chen et al. 1991). Finally, several groups have shown that silenced DNA is relatively inaccessible to DNA methylation catalyzed by heterologous DNA methylating enzymes expressed ectopically in yeast (Gottschling 1992; Singh and Klar 1992). These latter observations suggest that silenced DNA is packaged by chromatin in vivo in a manner that renders it less accessible than expressed regions of the genome.

Transcriptional levels of a variety of eukaryotic genes are directly correlated with the level of nucleosome acetylation of lysine residues located within the aminoterminal region of the core histones (Matthews and Waterberg 1985; Turner 1991). For example, core his- tones in the transcriptionally inactive micronuclei of Tetrahymena are predominantly hypoacetylated, whereas histones in the transcriptionally active macronuclei are generally acetylated at multiple sites ( $\mathrm{Lin}$ et al. 1989|. Similarly, the active $\beta$-globin gene is enriched in fractions of hyperacetylated nucleosomes from chicken erythrocyte chromatin, whereas the inactive ovalbumin gene is not (Hebbes et al. 1988). The causal relationship between acetylation and activated transcription is not known, although reduced acetylation may facilitate formation of the higher order chromatin structure associated with inactive heterochromatin (van Holde 1989; Wolffe 1991).

In light of these observations, we sought to test the hypothesis that one or more of the SIR gene products specifically affects histone modification and/or chromatin structure. The results of this analysis are presented in this report and provide evidence that the products of the SIR genes are required for deacetylation of nucleosomes that package silenced domains in yeast. These results confirm that silencing is a consequence of altered chromatin structure, provide the first indication of the functional activities of the Sir proteins, and present a very tractable system for probing the function of histone acetylation in eukaryotic cells.

\section{Results}

\section{Silenced DNA is packaged in hypoacetylated nucleosomes}

Prompted by the effects of mutations within the histone $\mathrm{H} 4$ gene on silencing and by the correlation between histone acetylation and gene expression, we examined the relationship between histone acetylation and transcriptional silencing in yeast. If histone acetylation is relevant to transcriptional silencing, we would predict that the nucleosomes that package the silent cassettes in a wild-type $\mathrm{SIR}^{+}$strain would be less acetylated than nucleosomes packaging the identical but active genes present at the MAT locus. In addition, this difference in the acetylation pattern would be lost if the silent cassettes are activated by mutational disruption of silencing.

To test these predictions, we made use of antibodies specific for acetylated histone $\mathrm{H} 4$. These antibodies were raised against a peptide corresponding to the amino-terminal 20 amino acids of Tetrahymena histone $\mathrm{H} 4$, of which all the conserved lysine residues that undergo reversible acetylation had been acetylated (Lin et al. 1989). The polyclonal antibodies obtained using this antigen cross-react with multiply acetylated histone $\mathrm{H} 4$ from Tetrahymena, but have significantly lower affinity for histone $\mathrm{H} 4$ with few acetylated lysine residues and do not react with unacetylated histone $\mathrm{H} 4$. As shown by indirect immunofluorescence and by immunoblotting analysis, these antibodies cross-react with histones in the active macronucleus of Tetrahymena but not with those in the micronucleus, confirming the specificity of the antibodies for active chromatin. We have also shown 
that the antibodies cross-react with multiply acetylated yeast histone $\mathrm{H} 4$, despite the presence of three amino acid differences in the amino-terminal region of yeast histone $\mathrm{H} 4$ versus that from Tetrahymena (data not shown).

We used these antibodies to assess the extent of acetylation of nucleosomes that package specific portions of the yeast genome, as outlined in Figure 1A. Chromatin was isolated from various yeast strains. Immediately before harvesting, cells were treated briefly with formaldehyde to cross-link chromatin proteins to their contiguous DNA sequences. The purified chromatin was fragmented into small segments and then immunoprecipitated with antibodies specific for multiply acetylated histone H4. The presence of specific DNA sequences within the immunoprecipitated chromatin could then be examined by reversing the cross-linking, extracting DNA from the precipitated nucleosomes, immobilizing the extracted DNA on nitrocellulose, and probing with sequences specific for the region in question.

To distinguish between silent and expressed matingtype loci in these experiments, we used a strain in which the $M A T$ locus carried the a mating-type genes and both $H M L$ and $H M R$ loci carried $\alpha$ mating-type genes. Thus, the fate of the silent loci sequences could be followed by hybridizing with an $\alpha$-specific probe, and the fate of the expressed MAT locus could be followed with an a-specific probe. The relative proportion of the a-specific or $\alpha$-specific sequences present in the precipitated chromatin versus that in total chromatin thus reflected the extent to which the chromatin packaging these different mating-type loci were acetylated in vivo.
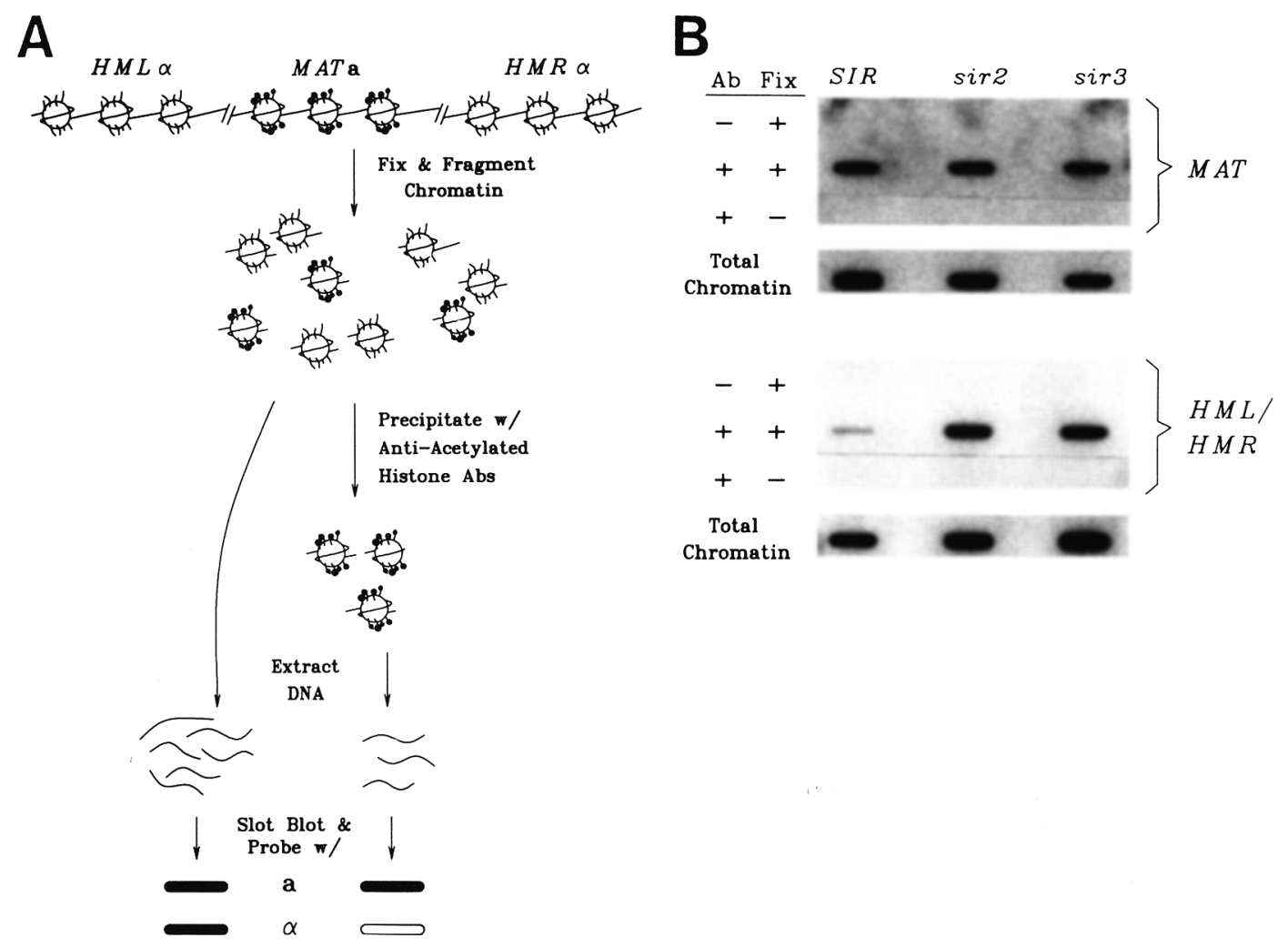

Figure 1. The silent mating-type cassettes are packaged in hypoacetylated chromatin in vivo in a SIR-dependent fashion. (A) Protocol for analyzing acetylation state of chromatin packaging different regions of the yeast genome. Total chromatin (top) is isolated from a yeast strain, fixed with formaldehyde, fragmented by sonication, and incubated with polyclonal anti-acetylated histone $\mathrm{H} 4$ antibodies. Samples of both the total chromatin and the antibody-precipitable chromatin are treated to reverse the fixation, and DNA is recovered from both fractions. These DNA samples are immobilized on nitrocellulose and then hybridized with probes from different portions of the genome. A strong signal in the precipitated fraction indicates that the corresponding region of the genome was packaged in hyperacetylated chromatin; a weak signal indicates that the corresponding region was packaged in hypoacetylated chromatin. $(B)$ Chromatin solution was prepared as outlined in $A$ and described in Materials and methods from strains Y 851 (SIR), Y1422 (sir2), and Y1423 (sir3), either after fixation (+ Fix) or in the absence of fixation (-Fix). Nucleosomes were precipitated from the chromatin solution using antibodies against hyperacetylated histone $\mathrm{H} 4(+\mathrm{Ab})$ or in the absence of antibodies (- Ab). DNA isolated from the total chromatin and from the immunoprecipated material was immobilized on nitrocellulose filters using a slot-blot grid, and identical filters were hybridized with an a-specific probe to identify $M A T$ sequences or with an $\alpha$-specific probe to reveal $H M L / H M R$ sequences. The amount of total chromatin DNA in each control slot corresponded to $40 \%$ of the amount of chromatin solution represented in each immunoprecipitated sample. From control hybridizations not shown, the signal obtained with the total chromatin samples was equivalent that obtained from $\sim 0.4 \mu \mathrm{g}$ of total genomic yeast DNA applied to the filter. 
The results of this analysis, presented in Figure 1B, unequivocally confirmed the predictions laid out above. As evident, immunoprecipitation of chromatin from a $S I R^{+}$strain with the anti-hyperacetylated histone antibody yielded considerably less silent loci-specific DNA than it did MAT-specific DNA. This is true even though DNA corresponding to silent cassettes is present at levels equivalent to that of the MAT locus in the chromatin before precipitation. Thus, the silent mating-type loci are under-represented in hyperacetylated chromatin from a $S I R^{+}$strain, relative to the expressed MAT locus.

Hypoacetylation of nucleosomes spanning $H M L$ and $H M R$ was dependent on silencing. Silencing is alleviated in sir2, sir3, or sir4 strains: Such strains exhibit $H M L$ and $H M R$ transcription at levels comparable to that of $M A T$. As shown in Figure 1B, $H M L$ and $H M R$ sequences were precipitated by anti-hyperacetylated histone antibody from chromatin from both a sir2 and a sir 3 strain to the same extent as were MAT sequences. Thus, the acetylation level of chromatin spanning $H M L$ and $H M R$ is diminished relative to that spanning $M A T$ when $H M L$ and $H M R$ are silenced, but the acetylation levels are equivalent to that of $M A T$ when $H M L$ and $H M R$ are expressed. Identical results to the ones presented in Figure 1 were obtained with a sir4 strain and with a different set of isogenic $S I R^{+}$and sir $^{-}$strains (data not shown\}, indicating that these results are reproducible.

\section{Acetylation state correlates with silencing rather than transcription}

The results described above demonstrate that the silent mating-type cassettes are packaged in hypoacetylated nucleosomes in a $S I R^{+}$background but are packaged in normally acetylated nucleosomes in sir $^{-}$strains. Because the silent cassettes are transcribed in sir $^{-}$strains, these results do not allow us to distinguish whether the difference in acetylation in $\mathrm{SIR}^{+}$versus sir $^{-}$strains is a direct affect of silencing or an indirect effect of the different transcription rates of the mating-type cassettes in the two strain backgrounds.

To address this question directly, we examined the acetylated state of chromatin of a silent cassette that could not be transcribed. We constructed isogenic sir3 and SIR3 strains that carry only a single silent cassette, from which the promoter/enhancer elements had been removed. This was accomplished by inserting the $\alpha 1 \alpha 2$. C46 allele into the HML $\alpha$ locus of a MATa strain, from which the $H M R$ locus had been previously deleted. The $\alpha 1 \alpha 2$-C46 allele is a 46 -bp deletion within the divergent $\alpha 1-\alpha 2$ promoter that, when resident at $M A T$, completely eliminates transcription of both the $\alpha 1$ and $\alpha 2$ genes (Siciliano and Tatchell 1984). We confirmed that this allele eliminates expression of the $H M L \alpha$ locus: Strain YSH126 (hml $\alpha 1 \alpha 2-C 46$ MATa $h m r \Delta$ sir3) exhibits full a mating. Thus, neither the $\alpha 1$ nor the $\alpha 2$ gene at $H M L$ is active in this strain, even though silencing of the locus is completely eliminated.

We prepared chromatin from strain YSH126 and its isogenic $\mathrm{SIR}^{+}$derivative, strain $\mathrm{YSH} 129$, and then iso- lated hyperacetylated chromatin fractions as described in the previous section. As a control, we also prepared chromatin from the $H M L \alpha$ parents of both strains. As evident from the results shown in Figure 2, the hml locus is under-represented in the hyperacetylated fraction in chromatin isolated from the $S I R^{+}$strain but present at levels equivalent to that of MAT in chromatin isolated from the sir 3 strain. The proportion of antibody-precipitable chromatin packaging the transcription-defective $\mathrm{hml}$ locus in this set of strains is quantitatively identical to that observed for the transcription-competent $H M L$ locus in the isogenic control strains or in the set of strains used for the experiment shown in Figure 1 /Table 1). Thus, even in a situation in which the silent cassette is incapable of being transcribed, the acetylation state of the chromatin correlates with silencing. Thus, hypoacetylation of chromatin packaging the silent cassettes is a direct consequence of silencing, not an indirect consequence of the absence of transcription.

\section{Hypoacetylation is associated with other silenced regions of the genome}

We examined our antibody-fractionated chromatin to determine the extent to which chromatin from other regions of the yeast genome is acetylated. As noted in Figure 3 , the constitutively active actin gene, $A C T 1$, was found in the hyperacetylated fraction to an equal extent in $S I R^{+}$and Sir $^{-}$strains. In addition, the proportion of $A C T 1$ DNA precipitable by the anti-hyperacetylated antibodies was comparable to that of $M A T$, indicating that this constitutively active gene is packaged in acetylated chromatin (Table 1). Essentially the same pattern was obtained with the GAL1 gene, even though the strain

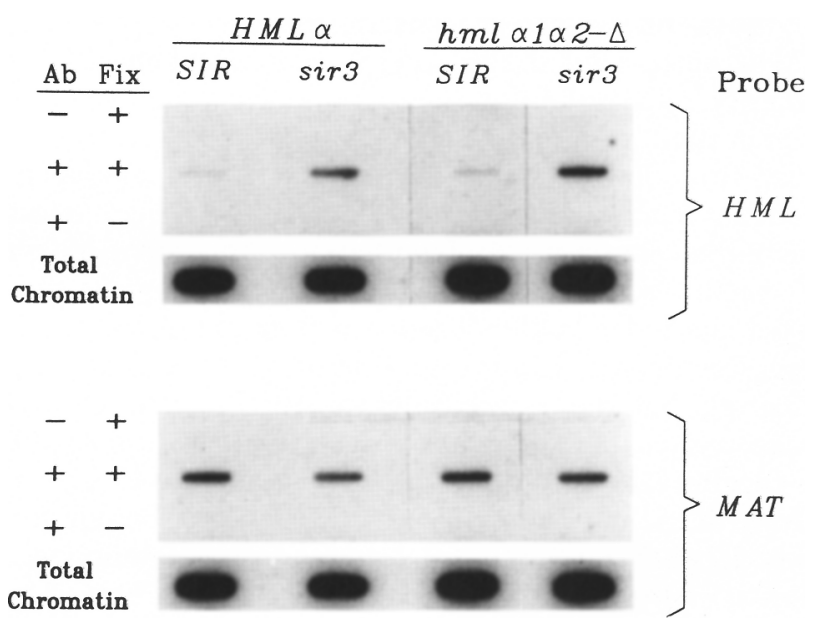

Figure 2. Acetylation patterns of a transcriptionally defective silent locus. Total chromatin was prepared from four isogenic MATa $h m r \Delta$ strains, carrying either a wild-type $H M L \alpha$ locus or a promoter-deficient $h m l$ locus $(h m l \alpha 1 \alpha 2-\Delta)$ and either a wildtype or inactive SIR3 locus. Chromatin was fractionated by immunoprecipitation, and DNA was extracted, prepared, and probed as described in the legend to Fig. 1. 
Table 1. Relative fraction of chromatin immunoprecipitable with anti-hyperacetylated antibody

\begin{tabular}{lllll}
\hline & \multicolumn{4}{c}{ Strain $^{\mathrm{a}}$} \\
\cline { 2 - 5 } Locus & SIR & sir2 & $\operatorname{sir} 3$ & $\operatorname{sir} 4$ \\
\hline MAT & 1.0 & 1.0 & 1.0 & 1.0 \\
HML/HMR & 0.05 & 0.92 & 0.87 & 0.67 \\
Y (telomeres) & 0.18 & 0.70 & 0.32 & - \\
GAL1 & 0.40 & 0.50 & 0.29 & - \\
ACT1 & 0.47 & 0.61 & 0.59 & - \\
MAT & 1.0 & - & 1.0 & - \\
HML & 0.08 & - & 0.86 & - \\
hm1 $1 \alpha 2$ & 0.10 & - & 1.1 & - \\
\hline
\end{tabular}

The labeled slots on the nitrocellulose filters used to generate the autoradiograph in Figs. 1-3 were quantitated with a PhosphorImager. The fraction of chromatin precipitated by anti-hyperacetylated antibody is indicated for each of the genes tested in each of the three strains, relative to the fraction of MATspecific chromatin precipitated from the chromatin fraction for each strain.

${ }^{a}$ Acetylation levels of the first group of loci were determined using isogenic strains Y851, Y1422, Y1423, and Y1462; those of the second group were determined using isogenic strains Y1197, YSH124, YSH126, and YSH129. (-) Not determined.

from which the chromatin was extracted was grown on glucose and, consequently, the GAL1 gene was not being transcribed. Nonetheless, the chromatin packaging this gene is relatively acetylated, indicating that reduced nucleosome acetylation is not associated with all forms of transcriptional repression in yeast. This observation highlights the distinction between SIR-mediated silencing and other forms of transcriptional repression in yeast and reinforces the conclusion from the previous section that hypoacetylation correlates with silencing, not simply with the absence of transcription.

The pattern for the telomere-specific sequence, $Y$, is slightly more complex. Less $\mathrm{Y}$-specific sequences are represented in the total chromatin fraction from $S I R^{+}$ than from $\operatorname{sir}^{-}$strains. This might reflect a Sir-dependent association of the yeast telomeres with the nuclear membrane or matrix. Nonetheless, the proportion of $\mathrm{Y}$-specific sequences precipitable by anti-hyperacetylated antibodes in the chromatin from the $S I R^{+}$strain was significantly lower than that of $A C T 1$ or GAL1, indicating that the $\mathrm{Y}$-specific chromatin is relatively hypoacetylated. A significantly greater proportion of the Y-specific chromatin from the sir2 strain was precipitable with the antibodies, indicating that hypoacetylation was dependent on SIR2. A less marked difference was noted with chromatin from the sir3 strain. This may reflect a more direct involvement of Sir $2 p$ than Sir3p in histone acetylation, as suggested below, although additional experiments will be required to resolve that point. In sum, these results indicate that both types of silenced sequences in yeast-telomeres and mating-type storage cassettes-are packaged in hypoacetylated chromatin, and this hypoacetylation is Sir dependent.

\section{SIR2 promotes histone deacetylation}

In light of these results, we sought to test the hypothesis that one or more of the SIR proteins specifically affects the level of histone acetylation. A difficulty in testing this hypothesis is that SIR proteins are present in very low amounts (Ivy et al. 1986), and their effects are limited primarily to $H M L, H M R$, and the telomeres. Thus, any effects of the SIR proteins would normally be restricted only to a small fraction of histones in the cell. To circumvent this limitation, we increased expression of the SIR genes by placing them under the control of an efficient promoter, in the expectation that high-level expression of the SIR genes would extend their effects to the entire genome and thereby make their activities experimentally accessible.

To amplify expression of the SIR genes, we placed them under the control of the GAL10 promoter in the high copy number plasmid YEp54 (Broach et al. 1983; Armstrong et al. 1990) and induced expression by adding galactose to cells carrying these plasmids. This procedure had been shown previously to yield inducible, highlevel production of Sir4p (Marshall et al. 1987). As is evident in Figure 4, similar results were obtained with SIR2 and SIR3. As determined by Western analysis, the level of Sir2p or Sir3p could be increased $>100$-fold following induction by galactose. Such expression had no effect on cell growth or viability within the time frame of the experiment (data not shown).

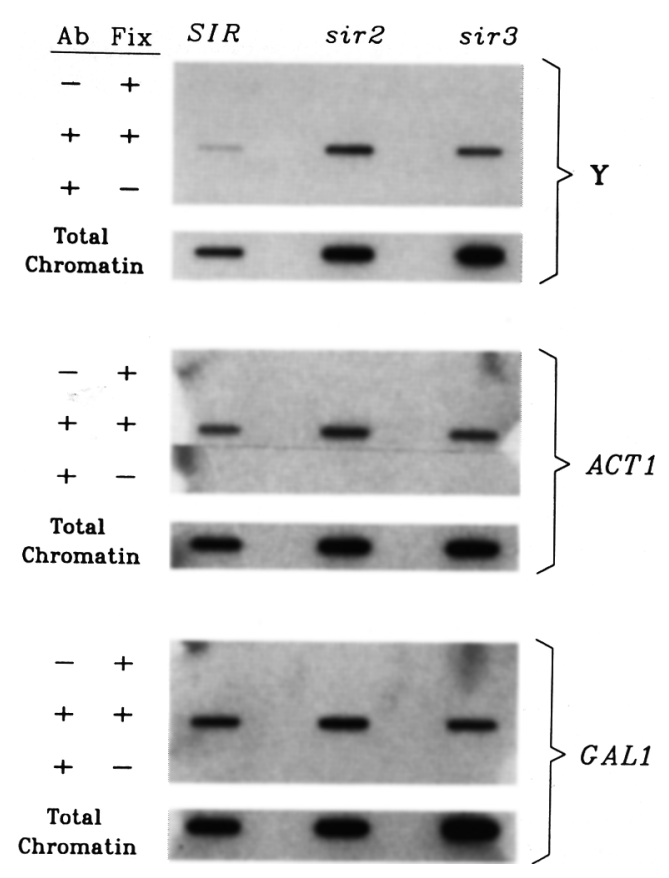

Figure 3. Acetylation patterns of other active and silenced genes in yeast. Filters identical to those described in Fig. 1 were probed with either a Y-specific probe /the 600-bp KpnI fragment from plasmid YRp131b), an ACT1-specific probe (the 286-bp BglII-ClaI fragment from plasmid pRB154), or a GAL1-specific probe (the 1.9-kb EcoRI-SalI fragment from plasmid pNN78). 


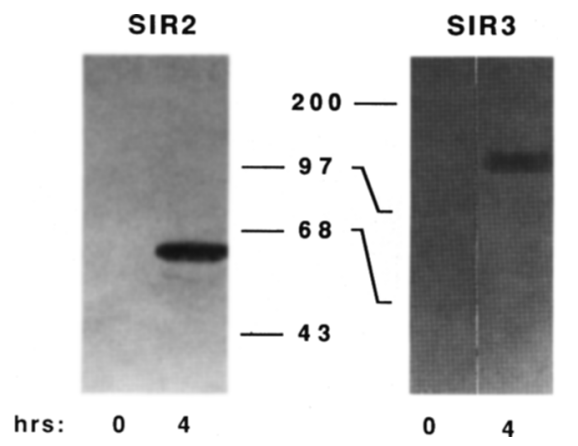

Figure 4. High level production of Sir $2 p$ and Sir3p. Strains BJ2169 [pAR44] (YEp-GAL-SIR2, left) and BJ2169 [pAR82] (YEpGAL-SIR3, right) were grown in SC - leucine plus raffinose at $30^{\circ} \mathrm{C}$ to a density of $10^{7}$ cells $/ \mathrm{ml}$, at which point galactose was added to $2 \%$ and incubation was continued. Samples $(50 \mathrm{ml})$ were removed at the time of galactose addition $(0 \mathrm{hr})$ and $4 \mathrm{hr}$ later, and extracts were prepared from harvested cells as described in Materials and methods. Samples $(0.01 \mathrm{ml})$ of the protein extracts were fractionated by polyacrylamide gel electrophoresis, transfered to nitrocellulose, and probed with antiSir2p serum (left) or anti-Sir3p serum (right) as described in Materials and methods. The positions of migration of size standards is indicated by the molecular mass (in $\mathrm{kD}$ ) of the proteins. The predicted molecular masses of Sir $2 p$ and Sir3p are 63 and $111 \mathrm{kD}$, respectively (Shore et al. 1984).

We examined the level and pattern of histone acetylation in wild-type cells and in cells overexpressing SIR2 or SIR3. This was accomplished by labeling cells with ${ }^{3} \mathrm{H}$-labeled acetate, extracting histones from the labeled cells and fractionating the histones on triton-acetic acid-urea polyacrylamide gels. As documented previously (Alfageme et al. 1974; Lin et al. 1989) and as evident from our analysis of wild-type cells (Figure 5, lane c), this gel system not only separated the various histone species but also clearly resolved the different acetylated forms of histone $\mathrm{H} 4$ and $\mathrm{H} 2 \mathrm{~B}$ and partially resolved those of histone $\mathrm{H} 3$. Because the cells were labeled for only a short time with ${ }^{3} \mathrm{H}$-labeled acetate, only acetylated forms of the histones were evident in the autoradiograph; unacetylated histones were not labeled and therefore not visible. In this gel system, the more highly acetylated histone species generally migrate more slowly than the less acetylated forms.

As evident in Figure 5, overexpression of SIR2 markedly decreased the amount of acetylation associated with several core histones, even though the amount of labeled acetate incorporated into the chromatin fraction was essentially identical for all of the strains. Incorporation of label into histone $\mathrm{H} 2 \mathrm{~A}$ was relatively uniform for all of the strains. In contrast, the amount of label incorporated into histones $\mathrm{H} 4, \mathrm{H} 2 \mathrm{~B}$, and $\mathrm{H} 3$ was substantially reduced in cells containing high levels of Sir2p (lane a), compared with isogenic cells with normal levels of Sir2p (lane c). Because equal amounts of both protein and label were loaded for all samples, the reduced amount of ${ }^{3} \mathrm{H}$ - labeled acetate found in histones from the Sir2p-overexpressing strain indicated that the average level of acetylation of these three core histones was substantially reduced in these cells. Consistent with this interpretation, overexpression of SIR2 also caused a qualitative change in the pattern of acetylation. The amount of histones $\mathrm{H} 4$ and H2B with multiple acetyl groups was reduced, whereas that of the mono- and diacetylated species increased. Thus, both the level of histone acetylation and the distribution of acetyl groups per histone $\mathrm{H} 4$ and $\mathrm{H} 2 \mathrm{~B}$ were diminished following SIR2 overexpression. Identical results were obtained in four separate experiments with two separate strains (data not shown).

Similar results were obtained with a strain engineered so that the only histone $\mathrm{H} 4$ synthesized was deleted for residues $4-14$, a region that includes all but one of the lysine residues subject to reversible acetylation (Fig. 5, lanes $\mathrm{d}-\mathrm{f}$ ). This observation confirms the assignment of histone $\mathrm{H} 4$ in the gel system and documents the reproducibility of the effect of SIR2 overexpression on acetylation patterns of the other core histones.

We did not test the effect of SIR4 overexpression on histone acetylation. As evident in lanes b and e, however, SIR3 overexpression had no effect on histone acetylation, demonstrating that diminution of acetylation is not a general effect of overexpressing silencer proteins. From these results, we conclude that Sir2p acts specifically to reduce the total amount of acetylated lysines in

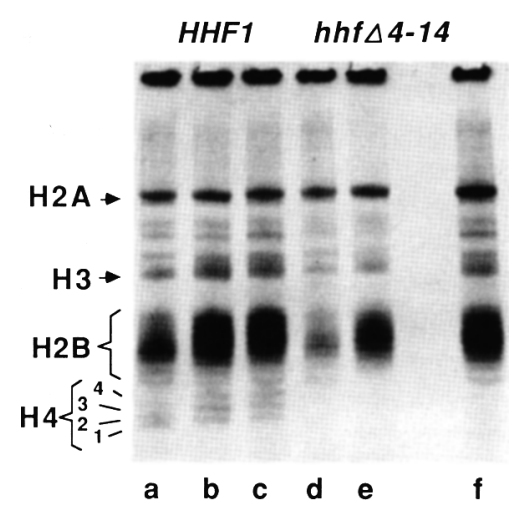

Figure 5. Sir2p promotes histone deacetylation. Cultures $(100$ ml) of strains Y1191 [pAR44] (YCp-HHF2 YEp-GAL::SIR2, lane a), Y1191 [pAR82] (YCp-HHF2 YEp-GAL::SIR3, lane b), Y1191 [YEp54] (YCp-HHF2 YEp-GAL, lane cl, Y1186 [pAR44] (YCp$h h f 2 \Delta 4-14$ YEp-GAL::SIR2, lane d), Y1186 [pAR82] (YCphhf2 4 -14 YEp-GAL::SIR3, lane $e$ ), and Y1186 [YEp54] (YCphhf2 $\Delta$ 4-14 YEp-GAL, lane $e$ ) were grown as in Fig. 4, and cells were harvested and converted to spheroplasts $2 \mathrm{hr}$ after the addition of galactose. Spheroplasts were labeled for $1 \mathrm{hr}$ with ${ }^{3} \mathrm{H}$ labeled acetate; histones were then extracted as described in Materials and methods. Equal samples (by cpm) were loaded in each lane of a 17-cm Triton-acetic acid-urea gel and fractionated by electrophoresis for $20 \mathrm{hr}$ at $200 \mathrm{~V}$. The gel was prepared for fluorography and exposed to film for 2 weeks at $-70^{\circ} \mathrm{C}$. The assignment of bands to histone species was made by comparison to published fractionations (indicated at left). The different acetylated species of histone $\mathrm{H} 4$ are also indicated. Duplicate gels were stained with Coomassie blue to estimate the relative amounts of protein in each lane. In the experiment shown, the amount of protein in any lane differed from the others by $<20 \%$. 
at least three of the four core histones as well as the average number of acetylated lysines within histones $\mathrm{H} 2 \mathrm{~B}$ and $\mathrm{H} 4$.

\section{Discussion}

\section{Silencing and histone acetylation in yeast}

Nucleosomes in chromatin of eukaryotic cells are reversibly acetylated on the $\epsilon$-amino groups of the multiple lysine residues spaced 1-8 amino acids apart near the amino terminus of all of the core histones. The level of acetylation of these lysines represents a dynamic equilibrium between competing reactions catalyzed by histone acetyltransferases and histone deacetylases (Allfrey et al. 1983; Turner 1991/. As noted in the introductory section, the extent of acetylation of the core histones correlates in many cases with the activity of the gene packaged by the histones.

We have provided evidence in this report that silencing of mating-type cassettes and telomeres in yeast is functionally intertwined with the extent of $\epsilon$-lysine acetylation of several of the core histones. We have shown that these silenced regions of the genome are packaged in nucleosomes that are hypoacetylated rela. tive to nucleosomes spanning active chromatin domains. Inactivation of sir2, or of other components of the silencing apparatus, eliminates this difference in acetylation patterns. Consistent with this observation, we have shown that Sir2p, which is required for silencing, promotes histone deacetylation in vivo. Thus, silenced DNA is packaged in hypoacetylated nucleosomes, and Sir2p promotes this hypoacetylation.

The result that we obtained with the anti-acetylated histone $\mathrm{H} 4$ antibody could formally be explained by postulating that the histone $\mathrm{H} 4$ amino-terminal tails are uniformly acetylated throughout the genome but simply masked in silenced chromatin. This explanation, however, is contrary to observations obtained in other organisms and not consistent with our results with Sir2p overexpression. That is, our observations are internally consistent and mutually supportive: Loss of Sir $2 p$ function leads to increased histone acetylation of the silenced domains of the genome las measured by antibody crossreactivity), whereas overexpression of Sir2p leads to decreased acetylation of histones in active regions of the genome (as measured by direct labeling of the acetyl groups). In addition, Lin et al. (1989) demonstrated that nucleosomes in the condensed micronuclei of Tetrahymena were not recognized by the antibodies used in this report but were recognized by antibodies raised against the unacetylated histone $\mathrm{H} 4$ amino-terminal domain. Similarly, Turner et al. (1990) found that regions of chromatin from Chironomus salivary gland that failed to cross-react with anti-acetylated histone antibodies were accessible to antibodies against hypoacetylated histones. Turner et al. \{1992\} also showed that, although different regions of Drosophila salivary chromosomes were differentially acetylated, both euchromatic and heterochromatic regions were accessible to one or more antibodies directed against histone $\mathrm{H} 4$ tails. Thus, in all of these cases, the failure of anti-acetylated histone antibodies to react with chromatin is attributable to differences in acetylation, not accessibility. Because the structure of yeast chromatin is unlikely to be significantly different from that of other eukaryotic cells, the level of crossreactivity of nucleosomes with the anti-acetylated histone antibody most likely reflects the level of acetylation of those nucleosomes, rather than their relative accessibility to the antibodies.

With the available data, we cannot distinguish whether Sir $2 p$ is a histone deacetylase or whether it inhibits a histone acetyltransferase. We have not been able to detect a difference in histone deacetylase activity in vitro in extracts prepared from SIR2-overexpressing cultures versus those from control cultures data not shown). If Sir2p acts by inhibiting an acetyltransferase, inhibition could be direct - through specific inactivation of an acetyltransferase enzyme-or indirect-by association of Sir $2 p$ with nucleosomes to restrict access of a histone acetyltransferase for its substrate. Further investigation is necessary to define the mechanism of Sir $2 p$ action. Nonetheless, we feel confident that the altered acetylation pattern induced by Sir2p overexpression is not an artifact of overexpression per se: The change in histone acetylation attendant on Sir2p expression occurs before any notable alteration in cell growth or viability, and similar overexpression of Sir3p has no effect on the acetylation pattern.

We have seen that the effects of Sir2p and Sir3p on nucleosome acetylation are assymmetric. Nucleosomes packaging the silent cassettes are hypoacetylated in $S^{+}{ }^{+}$strains and fully acetylated in both sir2 and sir3 strains. This indicates that both gene products are required for hypoacetylation of chromatin across the silent cassette. Overproduction of Sir $2 p$, however, yields general hypoacetylation, whereas overproduction of Sir3p does not. In fact, overexpression of Sir $2 p$ and Sir3p together causes no more hypoacetylation than does overexpression of Sir2p alone (data not shown). One possible explanation for this assymmetry is that Sir2p is directly responsible for hypoacetylation, whereas Sir3p serves primarily to localize Sir $2 p$ to the silent cassettes. This accounts for the above results and is also consistent with the hypothesis derived from genetic suppression studies that Sir3p may interact directly with the histone $\mathrm{H} 4$ amino-terminal domain (Johnson et al. 1990).

The acetylation effects of Sir2p are quite distinct from those catalyzed by the amino-terminal protein acetyltransferase encoded by $N A T 1$ and $A R D 1$, even though mutation of NAT1 or ARD1 also yields derepression of $H M L$ (Whiteway et al. 1987; Lee et al. 1989; Mullen et al. 1989). Natlp/Ardlp acetylates the amino-terminal residue of several dozen proteins, including histone H2B. Unlike the reversible acetylation of lysine residues affected by Sir2p, amino-terminal acetylation like that catalyzed by the NAT1/ARD1 protein is irreversible, cotranslational, and specific for the $\alpha$-amino group of a wide variety of proteins. Although the biological function of neither type of acetylation is completely under- 
stood, amino-terminal acetylation is thought primarily to increase protein stability rather than to alter gene expression (Tsunasawa and Sakiyama 1984).

\section{Does the correlation between silencing and histone acetylation reflect a functional connection?}

Although acetylation of nucleosomes correlates with gene expression, the basis for this correlation is not entirely clear. Acetylation neutralizes the positive charge of the lysine residues, which might be expected to reduce the avidity of the interaction between the nucleosome and the DNA wrapped around it (McGhee and Felsenfeld 1980). Physical measurements, however, have failed to identify a significant difference in the affinity of acetylated versus nonacetylated nucleosomes for DNA [Simpson 1978; Ausio and van Holde 1986; Libertini et al. 1988). Another possibility is that the charged amino termini of histones in the nucleosome facilitate interaction with the linker DNA between nucleosomes and with histone $\mathrm{Hl}$ (or a functional equivalent), which promotes formation of the solenoidal $30-\mathrm{nm}$ chromatin fiber (Norton et al. 1989; Ridsdale et al. 1990). Thus, acetylation would tend to disrupt the condensed $30-\mathrm{nm}$ fibers, whereas deacetylation would favor its formation. In this context, we would argue that Sir2p promotes deacetylation, which in turn promotes condensation of the silenced DNA into the $30-\mathrm{nm}$ fibers that comprise heterochromatin.

Recent observations suggest that acetylation of specific lysine residues has a more significant effect on gene expression than does acetylation of the nucleosomes as a whole. Park and Szostak (1990) showed that conversion of all the acetylatable lysines except Lys-16 in histone $\mathrm{H} 4$ in yeast to either arginine residues (mimicking the hypoacetylated state) or alanine residues (mimicking the acetylated state) had little effect on the level of silencing in the cell. In contrast, converting Lys-16 to alanine caused complete derepression of $H M L$, whereas converting it to arginine had little effect. This highlighted the critical role of Lys-16 of histone $\mathrm{H} 4$ in silencing-a conclusion concurrently reached and elaborated by Johnson et al. $(1990,1992)$-and prompted the hypothesis that the unacetylated form of histone $\mathrm{H} 4$ Lys- 16 facilitates silencing, whereas the neutral, or acetylated, form interferes with it. This potentially critical role of the acetylation of histone $\mathrm{H} 4$ Lys-16 in gene expression was highlighted further by recent observations indicating that nucleosomes containing histone $\mathrm{H} 4$ acetylated on Lys- 16 were specifically associated with the hyperexpressed $\mathrm{X}$ chromosome in male Drosophila (Turner et al. 1992). Thus, the association of acetylation of Lys-16 in Drosophila with enhanced expression is consistent with a role for Lys-16 in its unacetylated form in promoting silencing in yeast. In light of these observations, we might expect that the primary purpose of yeast histone deacetylation in relation to silencing is to maintain Lys-16 in its charged form. This may, for instance, facilitate specific critical protein-protein interactions between the nucleosome and other components of the silencing apparatus.
Deacetylation, heterochromatin formation, and reduced transcription are tightly correlated in eukaryotic cells. As noted in the introductory section, actively transcribed genes are enriched in chromatin hyperacetylated on histone $\mathrm{H} 4$. In addition, sodium butyrate, an inhibitor of histone deacetylase (Candido et al. 1978), induces changes in chromatin structure and stimulates transcription (Muller et al. 1982; Reczek et al. 1982). Also, a suppressor mutation [Su-var(2)1] of position effect variegation in Drosophila, a phenomenon in which local changes in heterochromatin structure affect the expression of adjacent euchromatic genes, causes significant hyperacetylation of histone $\mathrm{H} 4$ (Dorn et al. 1986). This is consistent with the hypothesis that the wild-type product of the Su-var(2) gene is a deacetylase for promotes deacetylation) and that this activity is required for heterochromatic silencing of otherwise active genes.

Although the correlation between deacetylation, heterochromatization, and silencing is well established, the causal relationships among these events are not well defined. Our results argue that $\operatorname{Sir} 2 \mathrm{p}$ may play a role in yeast similar to that of the Su-var(2) gene of Drosophila: It promotes deacetylation and is necessary to maintain chromatin in a silent state. However, Sir $2 \mathrm{p}$ activity-and thus deacetylation-alone is not sufficient for repression. Both Sir $3 p$ and Sir $4 p$ are required, in addition to Sir $2 p$, to maintain silencing, the former perhaps through direct interaction with the nucleosome (Johnson et al. 1990). Nonetheless, the results presented in this report begin to define the causal relationships underlying silencing and likely provide a guide for addressing the related phenomena of position effect variagation, $\mathrm{X}$ chromosome inactivation, and chromosome imprinting.

\section{Materials and methods}

\section{Plasmids}

Plasmids in which SIR2 or SIR3 expression was placed under the control of the GAL1O promoter were constructed from the expression vector YEp51 (Broach et al 1983) and plasmids pJH20.1 and pKAN56, containing the cloned SIR2 and SIR3 genes, respectively (Ivy et al. 1986). A Sall linker was inserted into the AccI site of plasmid pJH20.1, which lies 45 bp upstream of the initial ATG codon of SIR2. The 3.5-kb SalI-HindIII fragment from the resulting plasmid was inserted into YEp51, forming pAR 14. The 3.7-kb HpaI fragment from pKAN63 was ligated into the SmaI site of pUC12. This plasmid (pAR3) was linearized with SacI, treated with exonuclease BAL 31 , and reclosed in the presence of Sall linkers. The $3.5-\mathrm{kb}$ Sall-BamHI fragment from one of the recovered plasmids, in which the Sall site is $7 \mathrm{bp}$ upstream of the initial ATG codon of the SIR3 open reading frame, was inserted into YEp51 to create pAR16.

Plasmid pAR36, used to produce a chimeric TrpE-Sir2p protein to elicit anti-Sir2p antibodies, consists of the $2.7-\mathrm{kb}$ BgIIIHindIII fragment, spanning from codon 276 of SIR2 to the end of the gene, inserted into plasmid pATH3 (Dieckman and Tzagoloff 1985).

Chromosomal disruptions of SIR2 and SIR4 were created by use of plasmids C369 and pMM10.7, respectively, and disruptions of SIR3 were created by use of either plasmid C649 or pAR78. Plasmid C369 consists of YIp5 carrying a HindIII frag- 
ment spanning SIR2, into the BgIII site of which the 852-bp $E c o$ RI- BglII fragment containing TRP1 is inserted. Plasmid C649 consists of pBR322 carrying a BamHI-SalI fragment spanning SIR3, into the BgIII site of which a 4-kb BgIII fragment from YEpl3 containing the LEU2 gene is inserted. Plasmid pMM10.7 carries the sir4::HIS3-2 allele and has been described previously (Marshall et al. 1987). Plasmid pAR78 consists of pUC1 2 carrying a $2.6-\mathrm{kB}$ BamHI-PstI fragment spanning LEU2,

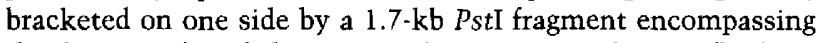
the first $750 \mathrm{bp}$ of the SIR3-coding region and its $5^{\prime}$-flanking sequence, and on the other side by a 400-bp HpaI-BamHI fragment encompassing the 3 '-flanking sequences of SIR3. Plasmid pSH100 consists of the BamHI-SacI fragment encompassing SIR 3 cloned into the corresponding sites of the TRP1-based YIp vector pRS404 (Sikorski and Hieter 1989).

Plasmid pAR63, used for truncation of chromosome III centromere-proximal to $H M R$, was derived from the chromosome truncation vector YCF3 (kindly provided by P. Hieter, Johns Hopkins University, Baltimore, MD), by inserting into its unique $E c o$ RI site the $0.6-\mathrm{kb} E c o$ RI fragment located immediately centromere-proximal to HMR. Plasmid pAR70 consists of pBR322 carrying in its Pvull site a 4.8 -kb fragment spanning LYS2. Introduction of the $\alpha 1 \alpha 2-\mathrm{C} 46$ allele into $H M L$ was accomplished using plasmid pSH101, which consists of YIp5 carrying at its HindIII site the $4.3-\mathrm{kb}$ HindIII fragment spanning the mat $\alpha$ l $\alpha 2$-C46 gene (Siciliano and Tatchell 1984).

Plasmids pDM44 and pDM71, used as sources of MATa- and $M A T \alpha$-specific probes, have been described previously (Mahoney and Broach 1989). Plasmids YRp131b [Chan and Tye 1983), pNN72 (St. John and Davis 1981), and pRB154 (Som et al. 1988) were used to generate Y-specific, GAL1-specific, and $A C T 1$-specific probes, respectively.

\section{Media and strains}

Synthetic medium $(\mathrm{SC})$ consisted of 6.7 grams/liter of yeast nitrogen base (Difco), supplemented with amino acids, adenine, and uracil as described (Sherman et al. 1979). Carbon sources were added to a concentration of $2 \%$. FOA plates are SC plates containing $1.0 \mathrm{mg} / \mathrm{ml}$ of 5 -fluoroorotic acid. YEPD consisted of $1 \%$ yeast extract, $2 \%$ bactopeptone, and $2 \%$ glucose.

Yeast strains used in this study are listed in Table 2 . Strains Y1422 and Y1423 were obtained by transforming strain Y851 to $\operatorname{Trp}^{+}$with HindIII-digested C369 DNA and to Leu ${ }^{+}$with BamHI plus Sall-digested C649 DNA, respectively. Strain Y1462 was obtained by transforming a his3 derivative of Y851 to $\mathrm{His}^{+}$with ClaI- plus ScaI-digested pMM10.7 plasmid DNA. The his3 derivative of strain Y851 was created by a two-step disruption of the HIS3 gene, using a YRp-URA-his3 200 plasmid, p510, provided by P. Hieter.

Strain Y1197 was obtained by first deleting $H M R$ from strain YPH49, by transforming it to Ura ${ }^{+}$with the chromosome fragmentation plasmid pAR63 DNA, and then converting the URA3 SUP11 markers at the site of trunction to LYS2 by a one-step transplacement, using pAR70 DNA. Strain YSH124 was obtained by transforming strain Y1197 to $\mathrm{Leu}^{+}$with BamHI plus HindIII-digested pAR78 DNA. Strain YSH126 was obtained from strain YSH124 by a two-step disruption procedure. $\mathrm{Ura}^{+}$transformants of strain YSH124, obtained with Hpal-digested pSH101 DNA, were screened by Southern analysis to identify those in which the plasmid DNA had integrated at $H M L$. Ura ${ }^{-}$revertants of one such transformant were obtained by plating on FOA plates and were screened for concomitant acquisition of a-mating capacity. That such revertants now carried the $\alpha 1 \alpha 2-\mathrm{C} 46$ allele at $H M L$ was confirmed by Southern analysis, and one was retained as strain YSH126. Introduction of the SIR3 gene into strain YSH126 was accomplished by transforming it to $\operatorname{Trp}^{+}$with $\mathrm{XbaI}$-digested pSH100, to yield strain YSH129. The presence of a functional SIR3 gene in YSH129 was confirmed by Southern analysis and by crossing it to strain Y1423 (HML $\alpha$ mata1 HMR $\alpha$ sir3) to observe that the diploid had the expected a mating-type.

Strain Y1191 was a segregant from a cross between strains PKY499 (Kayne et al. 1988) and AB8-16C. Isogenic derivatives of

Table 2. Strains used in this study

\begin{tabular}{|c|c|c|}
\hline Strain & Genotype & Source \\
\hline BJ2169 & MATa leu2-3,112 trp1 ura3-52 prb1-1122,407 pep4-3 & E. Jones (Carnegie Mellon University, Pittsburgh, PA) \\
\hline Y851 & mata1 $H M L \alpha H M R \alpha$ leu2-3,112 ura3-52 ade8 trp1 1901 & lab stock \\
\hline Y1422 & isogenic to Y851, sir2::TRP1 & this study \\
\hline Y1423 & isogenic to $\mathrm{Y} 851, \operatorname{sir} 3:: L E U 2$ & this study \\
\hline Y1462 & isogenic to $\mathrm{Y} 85 \mathrm{l}$, his $3 \Delta 200$ sir4::HIS3 & this study \\
\hline YPH49 & $\begin{array}{l}\text { MATa HMLa HMRa leu2-3,112 ura3-52 ade2-101 trp1- } \Delta 1 \\
\text { lys2-801 }\end{array}$ & P. Hieter (Johns Hopkins University, Baltimore, MD) \\
\hline Y1197 & 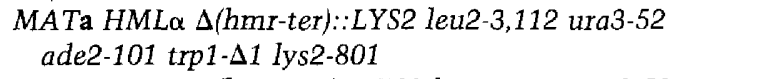 & this study \\
\hline YSH124 & $\begin{array}{l}\text { MATa } H M L \alpha \Delta(h m r-t e r):: L Y S 2 \text { leu2-3,112 ura3-52 } \\
\text { ade2-101 trp1- } \Delta 1 \text { lys2-801 sir3::LEU2 }\end{array}$ & this study \\
\hline YSH126 & $\begin{array}{l}\text { MATa } h m 1 \alpha 1 \alpha 2-C 46 \Delta(h m r-t e r):: L Y S 2 \text { leu2-3,112 } \\
\text { ura3-52 ade2-101 trp1- } \Delta 1 \text { lys2-801 sir3::LEU2 }\end{array}$ & this study \\
\hline YSH129 & 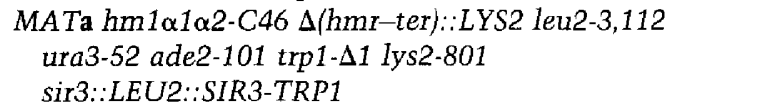 & this study \\
\hline $\mathrm{AB} 8-16 \mathrm{C}$ & 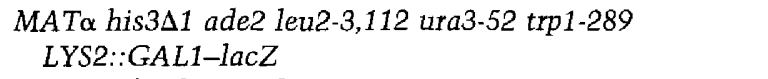 & lab stock \\
\hline Y1191 & 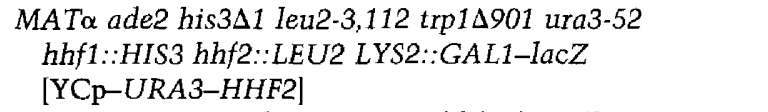 & this study \\
\hline Y1186 & isogenic to Y1191, [YCp-URA3-hhf2A(4-14)] & this study \\
\hline
\end{tabular}


Y1191 that differed only in the plasmid-borne hhf2 allele were derived from strain Y1191 by a plasmid shuffle procedure as follows. Strain Y1191 was transformed to $\mathrm{Trp}^{+}$with plasmid pMH310 (YCpTRP-HHF2), and a Ura ${ }^{-}$segregant of one such transformant was recovered. This segregant was transformed to $\mathrm{Ura}^{+}$with plasmid $\mathrm{pPK} 617$, and $\mathrm{Trp}^{-}$segregants of selected transformants were recovered to yield strain Y1186. SIR2- and SIR3-overexpressing versions of these strains were obtained by transforming each of them to $\operatorname{Trp}^{+}$with plasmid pAR44 or pAR82, respectively.

\section{Immunological procedures}

Preparation of antibodies Anti-Sir2p antibodies were raised in New Zealand rabbits to a TrpE-Sir2 fusion protein that was isolated as described (Dieckmann and Tzagoloff 1985) from E. coli strain RR1 containing plasmid pAR36. Antibodies against Sir3p were also raised in rabbits using a synthetic peptide corresponding to the predicted carboxy-terminal 22 amino acids of Sir3p coupled to keyhole limpet hemocyanin by the $N$-maleimidobenzoyl- $N$-hydroxy succinimide ester method (Liu et al. 1979; Green et al. 1982). In both cases, rabbits were injected subcutaneously in Freund's adjuvant with $250 \mu \mathrm{g}$ of antigen initially and $40-50 \mu \mathrm{g}$ in subsequent boosts. Preparation and characterization of antibodies against multiply acetylated histone H4 protein have been described previously (Lin et al. 1989).

Western blots Western blots were performed essentially as described by Blake et al. (1984). Yeast cells were grown in SC media with the indicated carbon source to a density of $2 \times 10^{7}$ to $4 \times 10^{7}$ cells $/ \mathrm{ml}$. Cells were harvested, resuspended in $1 / 50$ volume buffer (10 mM Tris- $\mathrm{HCl}$ at $\mathrm{pH} 7.4,50 \mathrm{~mm}$ EDTA, $0.1 \%$ Triton X-100, $2 \mu \mathrm{g} / \mathrm{ml}$ of aprotinin, $0.1 \mu \mathrm{M}$ pepstatin $\mathrm{A}$ ), and disrupted by vortexing five times with glass beads for 1 min each time. Samples of the extract were fractionated by polyacrylamide gel electrophoresis, and the fractionated protein was transferred to nitrocellulose or GeneScreen Plus using a semidry blotter (American Bionetics) according to the manufacturer's instructions. Anti-Sir2p and anti-Sir3p antisera were used at $1: 300$ dilution, and blots were developed with goat anti-rabbit IgG conjugated to alkaline phosphatase /Sigma, 1: 1000 dilution).

\section{Determination of in vivo histone acetylation patterns}

Cultures of the indicated yeast strains were grown in SC plus raffinose medium at $30^{\circ} \mathrm{C}$ to a density of $5 \times 10^{6} \mathrm{cells} / \mathrm{ml}$, at which point galactose was added to a concentration of $2 \%$ and incubation was continued for an additional $3 \mathrm{hr}$. Cells were harvested and converted to spheroplasts as follows. Cells were resuspended in $0.1 \mathrm{mM}$ Tris- $\mathrm{HCl}$ (pH 9.4), $10 \mathrm{~mm}$ dithiothreitol (1 gram of cells $/ 2 \mathrm{ml}$ of buffer), incubated for $15 \mathrm{~min}$ at $30^{\circ} \mathrm{C}$, washed once in Sorbitol/HEPES (1.2 M Sorbitol, $20 \mathrm{mM}$ HEPES at $\mathrm{pH} 7.4$ ), and resuspended in $5 \mathrm{ml}$ of Sorbitol/HEPES plus $2 \mathrm{mg}$ of Zymolyase $100 \mathrm{~T}$ per gram of cells. After $30 \mathrm{~min}$ at $30^{\circ} \mathrm{C}, 10$ $\mathrm{ml}$ of $1.2 \mathrm{M}$ Sorbitol, $20 \mathrm{mM}$ PIPES (pH 6.8), and $1 \mathrm{mM} \mathrm{MgCl}_{2}$ per gram of cells was added and the spheroplasts were harvested by centrifugation.

Histones were labeled and extracted by a modification of the method of Alonso and Nelson (1986). Spheroplasts from 1 gram of cells were resuspended in $5 \mathrm{ml}$ of labeling buffer $(2 \mathrm{~mm}$ $\mathrm{MgCl}_{2}, 2 \%$ galactose, $0.3 \%$ casamino acids, $20 \%$ Sorbitol, 20 $\mathrm{mM} \mathrm{KH} \mathrm{KO}_{4}$ at $\mathrm{pH} \mathrm{6.2)} \mathrm{and} \mathrm{incubated} \mathrm{for} 15 \mathrm{~min}$ at $30^{\circ} \mathrm{C}$. ${ }^{3} \mathrm{H}$ labeled acetate $(5 \mathrm{mCi}, 3.3-3.6 \mathrm{Ci} / \mathrm{mmole})$ was added, and the incubation was continued for $1 \mathrm{hr}$. Spheroplasts were harvested, resuspended in $10 \mathrm{ml}$ of ice cold NIB $[0.25 \mathrm{M}$ sucrose, $60 \mathrm{mM}$ $\mathrm{KCl}, 15 \mathrm{~mm} \mathrm{NaCl}, 5 \mathrm{mM} \mathrm{MgCl}_{2}, 1 \mathrm{mM} \mathrm{CaCl}_{2}, 15 \mathrm{~mm} \mathrm{MES,} 0.8 \%$
Triton X-100, $0.1 \mathrm{~mm}$ phenylmethylsulfonyl fluoride (PMSF)], incubated at $0^{\circ} \mathrm{C}$ for $15 \mathrm{~min}$, washed twice with ice-cold NIB, resuspended in $2 \mathrm{ml}$ of $0.4 \mathrm{M} \mathrm{H}_{2} \mathrm{SO}_{4}$, and incubated at $0^{\circ} \mathrm{C}$ for 1 hr. After removing cellular debris by centrifugation, the supernatant was dialyzed against $95 \%$ ethanol at $4^{\circ} \mathrm{C}$ for at least $24 \mathrm{hr}$ with three changes of ethanol. The resulting precipitate was collected by centrifugation, air-dried, and resuspended in $0.1 \mathrm{ml}$ of loading buffer $(20 \%$ sucrose, $1 \% \beta$-mercaptoethanol, $5 \%$ acetic acid, $0.02 \%$ pyronin $\mathrm{Y}$ ).

Samples were boiled for $5 \mathrm{~min}$, and equal amounts of labeled material (as determined by $\mathrm{cpm}$ ) were loaded in each lane of a 17-cm Triton-acetic acid-urea gel [15\% (wt/vol) acrylamide, $0.1 \%$ (wt/vol) bisacrylamide, $8 \mathrm{M}$ urea, $5 \%$ (vol/vol) acetic acid, $0.3 \%$ Triton X-100, $0.5 \%(\mathrm{vol} / \mathrm{vol})$ TEMED, $0.06 \%(\mathrm{wt} / \mathrm{vol}) \mathrm{am}-$ monium sulfate], which had been prerun overnight at $200 \mathrm{~V}$ in $5 \%$ acetic acid running buffer. Into each lane, $0.03 \mathrm{ml}$ of Scavenge ( $8 \mathrm{M}$ urea, $5 \%$ acetic acid, $0.6 \mathrm{M}$ mercaptoethylamine) was loaded for the last hour of the prerun. Electrophoresis was for 20 $\mathrm{hr}$ at $200 \mathrm{~V}$, and gels were fixed for $30 \mathrm{~min}$ in $40 \%$ (vol/vol) methanol, $10 \%$ acetic acid, before preparation for fluorography as described (Bonner and Laskey 1974). Duplicate gels were stained with Coomassie blue to estimate the relative amount of protein in each lane. Preflashed film was exposed to dried gels for $2-20$ weeks at $-70^{\circ} \mathrm{C}$.

\section{Immunoprecipitation of nucleosomes}

Immunoprecipitation of chromatin with anti-acetylated histone $\mathrm{H} 4$ antibodies was performed by a modification of the procedure described by Dedon et al. (1991). Cells were grown to a density of $10^{7}$ cells $/ \mathrm{ml}$, at which point they were fixed by the addition of formaldehyde to a concentration of $1 \%$ and incubation at $23^{\circ} \mathrm{C}$ for $10 \mathrm{~min}$. Fixed cells $(50 \mathrm{ml})$ were harvested by centrifugation for $5 \mathrm{~min}$ at $2000 \mathrm{~g}$ and converted to spheroplasts as described in the preceding section. Spheroplasts were washed sequentially in $2.5 \mathrm{ml}$ of ice-cold PBS $\left(10 \mathrm{mM} \mathrm{NaH} \mathrm{PO}_{4}, 150 \mathrm{mM}\right.$ $\mathrm{NaCl}$ at $\mathrm{pH} 7.4), 2.5 \mathrm{ml}$ of buffer I $(0.25 \%$ Triton X-100, $10 \mathrm{mM}$ EDTA, $0.5 \mathrm{~mm}$ EGTA, $10 \mathrm{~mm}$ HEPES at $\mathrm{pH} 6.5$, and $2.5 \mathrm{ml}$ of buffer II $(200 \mathrm{~mm} \mathrm{NaCl}, 1 \mathrm{~mm}$ EDTA, $0.5 \mathrm{~mm}$ EGTA, $10 \mathrm{~mm}$ HEPES, pH 6.5) and then resuspended in $0.5 \mathrm{ml}$ of lysis buffer (1\% SDS, $10 \mathrm{~mm}$ EDTA, $50 \mathrm{~mm}$ Tris- $\mathrm{HCl}$ at $\mathrm{pH} 8.1,0.8 \mu \mathrm{g} / \mathrm{ml}$ of pepstatin A, $0.6 \mu \mathrm{g} / \mathrm{ml}$ of leupeptin, $1 \mathrm{~mm}$ PMSF/. The suspension was then sonicated 10 times for $10 \mathrm{sec}$ each and clarified by centrifugation for $10 \mathrm{~min}$ in a microcentrifuge. The supernatant was diluted 10 -fold with dilution buffer $11 \%$ Triton $\mathrm{X}-100,2 \mathrm{~mm}$ EDTA, $150 \mathrm{~mm} \mathrm{NaCl}, 20 \mathrm{~mm}$ Tris- $\mathrm{HCl}$ at $\mathrm{pH} 8.1$ | to yield the solubilized chromatin solution.

For immunoprecipitation, $1 \mathrm{ml}$ of solubilized chromatin solution was mixed with $7.5 \mu$ lof undiluted anti-acetylated histone $\mathrm{H} 4$ serum and incubated overnight at $4^{\circ} \mathrm{C}$. Sonicated phage $\lambda$ DNA $(2 \mu \mathrm{g})$ and protein A-Sepharose $4 \mathrm{~B}$ beads $\{45 \mu \mathrm{l}$ of a $50 \%$ suspension in $10 \mathrm{~mm}$ Tris- $\mathrm{HCl}$ at $\mathrm{pH} 8,1 \mathrm{~mm}$ EDTA; Zymed Laboratories, Inc.) were added, and the incubation continued for $\mathrm{l} \mathrm{hr}$. Beads were then harvested by centrifugation and incubated sequentially for $10 \mathrm{~min}$ each in TSE $10.1 \%$ SDS, $1 \%$ Triton $\mathrm{X}-100,2 \mathrm{~mm}$ EDTA, $20 \mathrm{~mm}$ Tris- $\mathrm{HCl}$ at $\mathrm{pH} 8.1$ ) plus $150 \mathrm{~mm}$ $\mathrm{NaCl}$, TSE plus $500 \mathrm{~mm} \mathrm{NaCl}$, and buffer III $10.25 \mathrm{M} \mathrm{LiCl}, 1 \%$ Nonidet P-40, 1\% deoxycholate, 1 mM EDTA, $10 \mathrm{~mm}$ Tris- $\mathrm{HCl}$ at $\mathrm{pH}$ 8.1). The beads were then washed three times with $\mathrm{TE}$ and then extracted three times with $1 \%$ SDS, $0.1 \mathrm{~m} \mathrm{NaHCO}$. The pooled eluates were heated to $65^{\circ} \mathrm{C}$ for $4 \mathrm{hr}$ to reverse the formaldehyde cross-links, and the released DNA was precipitated with ethanol. Precipitates were resuspended in $20 \mu \mathrm{l}$ of TE, digested with proteinase $\mathrm{K}$ (Maniatis et al. 1982), extracted with phenol/chloroform $(1: 1)$, and then ethanol precipitated. The precipitates were resuspended in $40 \mu \mathrm{l}$ of TE and, after boiling 
for $5 \mathrm{~min}, 10-\mu \mathrm{l}$ aliquots were applied to nitrocellulose filters, using a slot-blot apparatus. The filters were hybridized with the indicated DNA probes, ${ }^{32} \mathrm{P}$-labeled by random primer incorporation (Maniatis et al. 1982).

Control samples from total chromatin were prepared by the incubation of $400 \mu \mathrm{l}$ of chromatin solution at $65^{\circ} \mathrm{C}$ for $4 \mathrm{hr}$ and then precipitation with ethanol. The precipitated samples were resuspended, treated with proteinase $\mathrm{K}$, extracted with chloroform, ethanol precipitated, and resuspended in $40 \mu \mathrm{l}$ of TE. Aliquots $\{10 \mu l)$ were applied to nitrocellulose filters and treated as described above.

\section{Acknowledgments}

We gratefully acknowledge the generous gifts of plasmids from Drs. Michael Grunstein, Phil Hieter, and Virginia Zakian. This research was supported by a grant from the American Cancer Society.

The publication costs of this article were defrayed in part by payment of page charges. This article must therefore be hereby marked "advertisement" in accordance with 18 USC section 1734 solely to indicate this fact.

\section{References}

Abraham, J., K.A. Nasmyth, J.N. Strathern, A.J.S. Klar, and J.B. Hicks. 1984. Regulation of mating-type information in yeast: Negative control requiring sequences both $5^{\prime}$ and $3^{\prime}$ to the regulated region. J. Mol. Biol. 176: 307-331.

Alfageme, C.R., A. Zweidler, A. Mahowald, and L.H. Cohen. 1974. Histones of Drosophila embryos. I. Biol. Chem. 249: 3729-3736.

Allfrey, V.G., R. Sterner, and I.Y.C. Sun. 1983. Affinity probes for protein acetylation and phosphorylation. In Postranslational covalent modifications of proteins (ed. B.C. Johnson), pp. 181-203. Academic Press, New York.

Alonso, W.R. and D.A. Nelson. 1986. A novel yeast histone deacetylase: Partial characterization and development of an activity assay. Biochim. Biophys. Acta 866: 161-169.

Aparicio, O.M., B.L. Billington, and D.E. Gottschling. 1991. Modifiers of position effect are shared between telomeric and silent mating-type loci in S. cerevisiae. Cell 66: 12791288.

Armstrong, K.A., T. Som, F.C. Volkert, A.B. Rose, and J.R. Broach. 1990. Propagation and expression of genes in yeast using 2-micron circle vectors. In Yeast genetic engineering (ed. P.J. Barr, A.J. Brake, and P. Valenzuela), pp. 165-192. Butterworths, Stoneham, MA.

Ausio, J. and K.E. van Holde. 1986. Histone hyperacetylation: Its effects on nucleosome conformation and stability. Biochemistry 25: 1421-1427.

Blake, M.S., K.H. Johnston, G.J. Russell-Jones, and E.C. Gotschlich. 1984. A rapid, sensitive method for detection of alkaline phosphatase conjugated anti-antibody on western blots. Anal. Biochem. 136: 175-179.

Bonner, W.M. and R.A. Laskey. 1974. A film detection method for tritium-labelled proteins and nucleic acids in polyacrylamide gels. Eur. J. Biochem. 46: 83-88.

Brand, A.H., L. Breeden, J. Abraham, R. Sternglanz, and K. Nasmyth. 1985. Characterization of a silencer in yeast: A DNA sequence with properties opposite to those of a transcriptional enhancer. Cell 41: 41-48.

Brand, A.H., G. Micklem, and K. Nasmyth. 1987. A yeast silencer contains sequences that can promote autonomous plasmid replication and transcriptional activation. Cell 51:
709-719.

Broach, J.R., Y.Y. Li, L.C.C. Wu, and M. Jayaram. 1983. Vectors for high-level, inducible expression of cloned genes in yeast. In Experimental manipulation of gene expression led. $\mathrm{M}$. Inouyel, pp. 83-117. Academic Press, New York.

Brown, C.J., R.G. Lafreniere, V.E. Powers, G. Sebastio, A. Ballabio, A.L. Pettigrew, D.H. Ledbetter, E. Levy, I.W. Craig, and H.F. Willard. 1991. Localisation of the X inactivation center on the human X chromosome in Xq13. Nature 349: 82.

Candido, E.P., R. Reeves, and J.R. Davie. 1978. Sodium butyrate inhibits histone deacetylation in cultured cells. Cell 14: 105-113.

Chan, C.S.M. and B.-K. Tye. 1983. A family of Saccharomyces cerevisiae repetitive autonomously replicating sequences that have very similar genomic environments. I. Mol. Biol. 168: 505-523.

Chen, T.A., M.M. Smith, S.Y. Le, R. Sternglanz, and V.G. Allfrey. 1991. Nucleosome fractionation by mercury affinity chromatography. Contrasting distribution of transcriptionally active DNA sequences and acetylated histones in nucleosome fractions of wild-type yeast cells and cells expressing a histone $\mathrm{H} 3$ gene altered to encode a cysteine 110 residue. J. Biol. Chem. 266: 6489-98.

Conrad, M.N., J.H. Wright, A.J. Wolf, and V.A. Zakian. 1990. RAPl protein interacts with yeast telomeres in vivo: Overproduction alters telomere structure and decreases chromosome stability. Cell 63: 739-750.

Dedon, P.C., J.A. Soults, C.D. Allis, and M.A. Gorovsky. 1991. A simplified formaldehyde-fixation and immunoprecipitation technique for studying protein-DNA interactions. Anal. Biochem. 197: 83-90.

Dieckmann, C.L. and A. Tzagoloff. 1985. Assembly of the mitochondrial membrane system. J. Biol. Chem. 260: 15131520 .

Dorn, R., S. Heymann, R. Lindigkeit, and G. Reuter. 1986. Suppressor mutation of position-effect variegation in Drosophila melanogaster affecting chromatin properties. Chromosoma 93: 398-403.

Feldman, J.B., J.B. Hicks, and J.R. Broach. 1984. Identification of the sites required for repression of a silent mating-type locus in yeast. I. Mol. Biol. 178: 815-834.

Gottschling, D.E. 1992. Telomere-proximal DNA in Saccharomyces cerevisiae is refractory to methyltransferase activity in vivo. Proc. Natl. Acad. Sci. 89: 4062-4065.

Gottschling, D.E., O.M. Aparicio, B.L. Billington, and V.A. Zakian. 1990. Position effect at $S$. cerevisiae telomeres: Reversable repression of pol II transcription. Cell 63: 751-762.

Green, N., H. Alexander, A. Olson, S. Alexander, T.M. Shinnick, J.G. Sutcliff, and R.A. Lerner. 1982. Immunogenic structure of the influenza virus hemagglutinin. Cell 28: $477-487$.

Haber, J.E. and J.P. Geroge. 1979. A mutation that permits the expression of normally silent copies of mating-type information in Saccharomyces cerevisiae. Genetics 93: 13-35.

Hall, J.G. 1990. Genomic imprinting: Review and relevance to human diseases. Am. I. Hum. Genet. 46: 857.

Hebbes, T.R., A.W. Thorne, and C. Crane-Robinson. 1988. A direct link between core histone acetylation and transcriptionally active chromatin. EMBO I. 7: 1395-1402.

Herskowitz, I. 1988. Life cycle of the budding yeast Saccharomyces cerevisiae. Microbiol. Rev. 52: 536-553.

- 1989. A regulatory hierarchy for cell specialization in yeast. Nature 342: 749-757.

Hicks, J.B., J.N. Strathern, and A.J.S. Klar. 1979. Transposable mating-type genes in Saccharomyces cerevisiae. Nature 282: 478-483. 
Ivy, J.M., A.J.S. Klar, and J.B. Hicks. 1986. Cloning and characterization of four $S I R$ genes of Saccharomyces cerevisiae. Mol. Cell. Biol. 6: 688-702.

Johnson, L.M., P.S. Kayne, E.S. Kahn, and M. Grunstein. 1990. Genetic evidence for an interaction between SIR3 and histone $\mathrm{H} 4$ in the repression of the silent mating loci in Saccharomyces cerevisiae. Proc. Natl. Acad. Sci.. 87: 62866290.

Johnson, L.M., G. Fisher-Adams, and M. Grunstein. 1992. Identification of a non-basic domain in the histone $\mathrm{H} 4 \mathrm{~N}$-terminus required for repression of the yeast silent mating loci. EMBO I. 11: 2201-2209.

Kayne, P.S., U.J. Kim, M. Han, J.R. Mullen, F. Yoshizaki, and M. Grunstein. 1988. Extremely conserved histone H4 N terminus is dispensable for growth but essential for repressing the silent mating loci in yeast. Cell 55: 27-39.

Klar, A.J.S., S. Fogel, and K. MacLeod. 1979. MAR1-A regulator of HMa and HM $\alpha$ loci in Saccharomyces cerevisiae. Genetics 93: 37-50.

Klar, A.J.S., J.N. Strathern, and J.B. Hicks. 1981. A positioneffect control for gene transposition: State of expression of yeast mating-type genes affects their ability to switch. Cell 25: 517-524.

Lee, F.J.S., L.W. Lin, and J.A. Smith. 1989. N-acetylation is required for normal growth and mating of Saccharomyces cerevisiae. J. Bacteriol. 171: 5795-5802.

Libertini, L.J., J. Ausio, K.E. van Holde, and E.W. Small. 1988. Histone hyperacetylation: Its effects on nucleosome core particle transitions. Biophys. I. 53: 477-487.

Lin, R., J.W. Leone, R.G. Cook, and C.D. Allis. 1989. Antibodies specific to acetylated histones document the existence of deposition- and transcription-related histone acetylation in Tetrahymena. I. Cell Biol. 108: 1577-1588.

Liu, F.T., M. Zinnecker, T. Hamaoka, and D.H. Katz. 1979. New procedures for preparation and isolation of conjugates of proteins and a synthetic copolymer of $\mathrm{D}$-amino acids and immunochemical characterization of such conjugates. Biochem. 18: 690-697.

Lyon, M.F. 1961. Gene action in the X chromosome of the mouse (Mus musculus L.). Nature 190: 373.

-1988. X-chromosome inactivation and the location and expression of X-linked gene. Am. J. Hum. Genet. 42: 8 .

Mahoney, D.J. and J.R. Broach. 1989. The HML mating-type cassette of Saccharomyces cerevisiae is regulated by two separate but functionally equivalent silencers. Mol. Cell. Biol. 9: 4621-4630.

Mahoney, D.J., R. Marquardt, G.J. Shei, A.B. Rose, and J.R. Broach. 1991. Mutations in the HML E silencer of Saccharomyces cerevisiae yield metastable inheritance of transcriptional repression. Genes \& Dev. 5: 605-615.

Maniatis, T., E.F. Fritsch, and J. Sambrook. 1982. Molecular cloning: A laboratory manual. Cold Spring Harbor Laboratory, Cold Spring Harbor, New York.

Marshall, M., D.M. Mahoney, A. Rose, J.B. Hicks, and J.R. Broach. 1987. Functional domains of SIR4, a gene required for position effect regulation in Saccharomyces cerevisiae. Mol. Cell. Biol. 7: 4441-4452.

Matthews, H.R. and J.H. Waterborg. 1985. Reversible modifications of nuclear proteins and their significance. In The enzymology of posttranslational modification of proteins (ed. R.B. Freedman and H.C. Hawkins|, pp.125-185. Academic Press, Orlando, FL.

McGhee, J.D. and G. Felsenfeld. 1980. Nucleosome structure. Annu. Rev. Biochem. 49: 1115-1156.

McNally, F.J. and J. Rine. 1991. A synthetic silencer mediates SIR-dependent functions in Saccharomyces cerevisiae. Mol.
Cell. Biol. 11: 5648-5659.

Megee, P.C., B.A. Morgan, B.A. Mittman, and M.M. Smith 1990. Genetic analysis of histone H4: Essential role of lysines subject to reversible acetylation. Science 247: 841845.

Mullen, J.R., P.S. Kayne, R.P. Moerschell, S. Tsunasawa, M. Gribskov, M. Colavito-Shepanski, M. Grunstein, F. Sherman, and R. Sternglanz. 1989. Identification and characterization of genes and mutants for an N-terminal acetyltransferase from yeast. EMBO I. 8: 2067-2075.

Muller, S., M. Erard, E. Burggraf, M. Couppez, P. Santiere, M. Champagne, and M.H.V. van Regenmortel. 1982. Immunochemical detection of changes in chromatin subunits induced by histone $\mathrm{H} 4$ acetylation. EMBO I. 1: 939-944.

Nasmyth, K.A. 1982. The regulation of yeast mating-type chromatin structure by SIR: An action at a distance affecting both transcription and transposition. Cell 30: 567-578.

Nasmyth, K.A., K. Tatchell, B.D. Hall, C.R. Astell, and M. Smith. 1981. A position effect in the control of transcription at yeast mating-type loci. Nature 289: 244-250.

Norton, V.G., B.S. Imai, P. Yau, and E.M. Bradbury. 1989. Histone acetylation reduces nucleosome core particle linking number changes. Cell 57: 449-457.

Park, E.C. and J.W. Szostak. 1990. Point mutations in the yeast histone $\mathrm{H} 4$ gene prevent silencing of the silent mating-type locus HML. Mol. Cell. Biol. 10: 4932-4934.

Pillus, L. and J. Rine. 1989. Epigenetic inheritance of transcription states in $S$. cerevisiae. Cell 59: 637-647.

Reczek, P., D. Weissman, P.E. Huvos, and G.D. Fasman. 1982. Sodium butyrate induced structural changes in HeLa cell chromatin. Biochem. 21: 993-944.

Ridsdale, J.A., M.J. Hendzel, G.P. Delcuve, and J.R. Davie. 1990. Histone acetylation alters the capacity of the $\mathrm{H} 1$ histones to condense transcriptionally active/competent chromatin. $J$. Biol. Chem. 265: 5150-5156.

Rine, J. and I. Herskowitz. 1987. Four genes responsible for a position effect on expression from $H M L$ and $H M R$ in Saccharomyces cerevisiae. Genetics 116: 9-22.

Rine, J.D., J.N. Strathern, J.B. Hicks, and I. Herskowitz. 1979. A suppressor of mating-type locus mutations in Saccharomyces cerevisiae: Evidence for and identification of cryptic mating-type loci. Genetics 93: 877-901.

St. John, T.P. and R.W. Davis. 1981. The organization and transcription of the galactose gene cluster of Saccharomyces. $J$. Mol. Biol. 152: 285-316.

Schnell, R. and J. Rine. 1986. A position effect on the expression of a tRNA gene mediated by the SIR genes in Saccharomyces cerevisiae. Mol. Cell. Biol. 6: 494-501.

Sherman, F., G.R. Fink, and J.B. Hicks. 1979. Methods in yeast genetics. Cold Spring Harbor Laboratory, Cold Spring Harbor, New York.

Shore, D., M. Squire, and K. Nasmyth. 1984. Characterization of two genes required for the position-effect control of yeast mating-type genes. EMBO J. 3: 2817-2823.

Siciliano, P.G. and K. Tatchell. 1984. Transcription and regulatory signals at the mating-type locus in yeast. Cell 37: 969978.

Sikorski, R.S. and P. Hieter. 1989. A system of shuttle vectors and yeast host strains designed for efficient manipulation of DNA in Saccharomyces cerevisiae. Genetics 122: 19-27.

Simpson, R.T. 1978. Structure of chromatin containing extensively acetylated H3 and H4. Cell 13: 691-699.

Singh, J. and A.J.S. Klar. 1992. Active genes in budding yeast display enhanced in vivo accessibility to foreign DNA methylases: A novel in vivo probe for chromatin structure of yeast. Genes \& Dev. 6: 186-196. 
Solter, D. 1988. Differential imprinting and expression of maternal and paternal genomes. Annu. Rev. Genet. 22: 127146.

Som, T., K.A. Armstrong, F.C. Volkert, and J.R. Broach. 1988. Autoregulation of $2 \mu \mathrm{m}$ circle gene expression provides a model for maintenance of stable plasmid copy number. Cell 52: $27-37$.

Tsunasawa, S. and F. Sakiyama. 1984. Amino-terminal acetylation of protein, an overview. Methods Enzymol. 106: 165170 .

Turner, B.M. 1991. Histone acetylation and control of gene expression. J. Cell Sci. 99: 13-20.

Turner, B.M., L. Franchi, and H. Wallace. 1990. Islands of acetylated histone $\mathrm{H} 4$ in polytene chromosomes and their relationship to chromatin packaging and transcriptional activity. I. Cell Sci. 96: 335-346.

Turner, B.M., A.J. Birley, and J. Lavender. 1992 Histone H4 isoforms acetylated at specific lysine residues define individual chromosome and chromatin domains in Drosophila polytene nuclei. Cell 69: 375-384.

van Holde, K.E. 1989. Chromatin. Springer-Verlag, New York.

Whiteway, M., R. Freedman, S. Van Arsdell, J.W. Szostak, and J. Thomer. 1987. The yeast $A R D 1$ gene product is required for repression of cryptic mating-type information at the $H M L$ locus. Mol. Cell. Biol. 7: 3713-3722.

Wolffe, A.P. 1991. Developmental regulation of chromatin structure and function. Trends Cell Biol. 1: 61-66. 


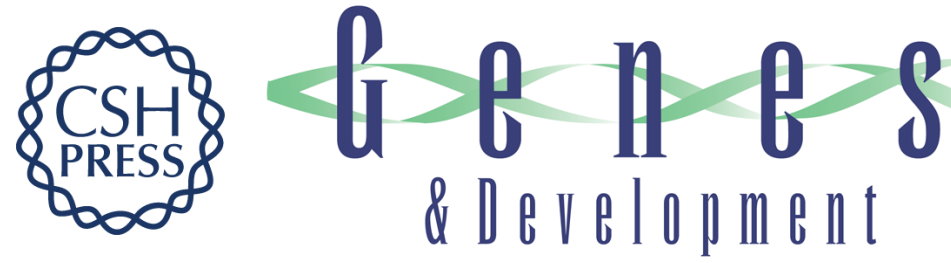

\section{Transcriptional silencing in yeast is associated with reduced nucleosome acetylation.}

M Braunstein, A B Rose, S G Holmes, et al.

Genes Dev. 1993, 7:

Access the most recent version at doi:10.1101/gad.7.4.592

References This article cites 71 articles, 26 of which can be accessed free at:

http://genesdev.cshlp.org/content/7/4/592.full.html\#ref-list-1

License

Email Alerting Receive free email alerts when new articles cite this article - sign up in the box at the top Service right corner of the article or click here.

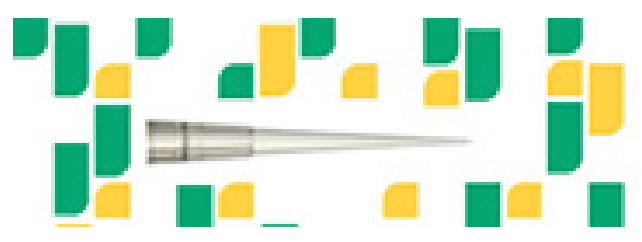

Focused on your science. 